\title{
The influence of national culture on tourists' behaviour towards environment
}

\author{
B. M. Farahani \& B. Mohamed \\ School of Housing Building and Planning, Universiti Sains, Malaysia
}

\begin{abstract}
Culture as an important element in tourism plays its role in the form of attraction for tourists as well as aspects which influence tourists' behaviour. Several crosscultural studies have been done to find the differences between tourists' behaviour regarding their culture. Although there is no comprehensive definition for culture in literature, Hofstede provided a well-known model which divided national culture into five dimensions. Power distance, individualism /collectivism, masculinity/femininity, uncertainty avoidance, and long-term orientation are the dimensions of his mentioned model. Since environment is the fundamental component of tourism, its sustainability, management, and controlling tourism impact on it is important for the industry. This study aims to review tourists' behaviour towards environment and find the influence of tourists' national culture on their certain behaviour. Qualitative analysis was done by using existing literature about "tourist behaviour in relation to environment" and relating them to "tourists' national culture". The result has provided the estimate model of tourist behaviour by different national culture towards environment.
\end{abstract}

Keywords: national culture, tourist behavior, environment.

\section{Introduction}

It is clear that environment both natural and man-made types has a significant role in tourism and its quality would be essential for the industry. Tourism with different activities which tourists involve may cause damages to the environment. In comprehensive view, tourists require services and amenities in order to travel and providing facilities such as roads, airports, hotels, restaurants, shops and so forth may cause direct or indirect damages in environment. 
It is needed to mention that tourism also has potentiality to protect the environment by its different programs. Ecotourism would be a good example in this matter. Green tourism as well as alternative tourism also plays its role in this regards.

As mentioned before, environment plays an important role in tourism industry. Its significance could be seen in both decision making process as well as desire towards sustainability of environment. Taking the above argument in to account, it is clear that different tourists present dissimilar behaviour towards environment in relation to distinct factors. Among those influential factors, it seems that national culture influences tourists' behaviour more than others. Quit number of study was done to find the influence of tourists' national culture on their behaviour in different stage of their trips. The result shows that people with the same national culture more or less have the same behaviour while travelling. It is confirmed that, having the knowledge of tourist national culture and its influence on behaviour would help the management, planner as well as policy makers to be aware of their market segments' behaviour to do their job in a better way and keep them loyal for a long time.

\section{Definition of culture}

The nature of culture is pervasive and broad which requires a detailed study of language, knowledge, laws, religions, food, customs, music, art, technology, work patterns, products and other artifact which give the society its distinctive flavor. Culture is the society personality and it helps to distinguish one society from another [1]. De Mooij [2] refers to culture as glue which binds groups together. He mentioned that culture includes whatever has worked in the past such as shared beliefs, attitudes, norms, roles, and values that usually transferred from generation to generation within the groups. According to the objective of consumer behavior studies (the influence of culture on consumer behavior), [1] culture is defined as "the sum total of learned beliefs, values, and customs that serve to direct the consumer behavior of member of a particular society" [1, p. 322].

Belief as a part of culture is people's feeling and priorities which consist of the very large number of verbal and mental statement. Simply when a person says "I believe....", which reflects his/her particular knowledge and assessment of that particular subject [1]. According to Rokeach [3] one of the early US researchers of value, "Value is an enduring belief that one mode of conduct or end-state of existence is preferable to an opposing mode of conduct or end-state of existence" [3, p. 5]. Values are preference of one state over the other like clean versus dirty, active versus passive, optimist versus pessimist and modern versus traditional [2].

Though, there are diverse definitions of culture in the literature, there is general agreement about using Hofstede [4] cultural model in social science study. Hofstede [4] developed a model of five dimensions of national culture that helps to understand basic values differences. In his model he distinguished 
cultures according to power distance, individualism/collectivism, masculinity /femininity, uncertainty avoidance, and long-term orientation.

\subsection{Hofstede national culture model}

"In 1980, the Dutch management researcher Greet Hofstede first published the result of his study of more than 100,000 employees multinational IBM in 40 countries" between 1967 and 1973 . He was challenging to find value dimensions towards cultural differences [5]. Hofstede classified four dimensions as power distance, individualism/collectivism, masculinity/femininity, and uncertainty avoidance for national culture values. He identified the fifth dimension as long /short-term orientation by the help of Bond in 1984. The second survey which helps to develop the fifth dimension was called "Chinese Values Survey" which was used to identify Asian typical culture. Accordingly, 50 countries are listed regarding the first four cultural dimensions while for the last dimension, only the analysis is available for 22 countries.

Geert Hofstede is the most well-known name in cultural studies [6] and his cultural model has broadly applied in the literature. Hofstede's cultural model is the most widely developed dimensions of national culture that allows differentiation among culture [7]. According to the Hofstede model, national culture includes five dimensions which will be the focus of this study. Hence, explanation of each dimension will be discussed in the following parts.

\subsubsection{Power Distance (PDI)}

It can be defined as the extent to which less powerful members of a society accept and expect that power is distinguished unequally. It influences the way people of the community give or accept authority. For example in Japanese culture everyone has his/her rightful place in social hierarchy and it is as natural for them as breathing [2]. On the other hand, the Danish do not have the same culture which affects their behavior in this matter. In high power distance culture there is strong dependency relationship with parents and children, bosses and employees, teachers and students. Conversely in low power distance culture, children are reared to be independent. One example of this group is the American who hates to be dependent on others or for others to be dependent on them.

In tourist behavior studies [8] the power distance culture dimension is positively related to tourists' tipping behavior. Tourists with high PD culture tip the service provider while travelling more that those who are from low PD culture. In general, tourists with high PD culture prefer to have a short trip compared to those with low PD culture. According to the Hofstede index, western countries have lower PD cultures compared to Asian countries. Accordingly this dimension of their culture influences their behavior while travelling.

\subsubsection{Uncertainty Avoidance (UAI)}

The range of avoidance of uncertainty and ambiguity among people is related to this part of national culture value. People with high uncertainty avoidance culture care about rules and they do not like to take risks while people with low 
uncertainty avoidance culture more willingly accept risk. They feel that there should be as few rules as possible and they are open to have different behavior when needed. Uncertainty avoidance reveals how much people with the same culture feel comfortable in unfamiliar or unstructured situations and the degree to which a society attempts to control the uncontrollable [9]. In the field of tourism, tourists with low UAI culture put more time to search for information about the destination they are travelling to, use different sources of information, travel on prepaid tours, travel in larger groups, stay for shorter times and visit fewer destinations compared to those with high UAI culture [10]. Money and Crotts [10] studied the effect of uncertainty avoidance on information search, planning and purchases of international travel vacations. They found different behavior by Japanese tourists with high UAI culture, compared to German tourists with low UAI culture. Litvin et al. [6] replicate the previous mentioned study and extend an alternative methodological approach to it. They found that the result of Money and Crotts [10] can be generalized to more tourists with same UAI culture to have similar behavior.

\subsubsection{Individualism/Collectivism (IDV)}

People only take care of their immediate family or those belonging to their group who take care of them in exchange for a sense of loyalty. In individualism culture, people are known by themselves while in collectivism culture people are recognized according to the group they belong to. In individualism culture, personal opinion and decision is more important than group decision and people with this culture prefer varieties while in collectivism culture, people care about their group and they prefer harmony rather than variety. As conclusion, in individualism culture, people use "I" while in collectivism culture, people use "we".

Examples for countries with individualism culture can be most western countries as well as north European countries while Asian, Latin American countries, and south European countries have collectivism culture. International tourists use different services and activities during their trip which each activity preference is related to different cultural dimensions. For example, individualism as one of national culture dimensions, clarifies differences in expenditure on sports and recreational service as well as recording media [2].

In individualistic culture [11], consumers go for realizing achievement and purchase status oriented product to show their success according to social standards while collectivist consumers may purchase items which confirm the social expectations. As Tuzun and Devrani [12] said, regarding individualism /collectivism orientation, some other studies have been done about the effect of those national culture dimensions on complaint behavior [13], green buying behavior [14] and service evaluation [15].

Hotel image is the most influential component to satisfy individualist tourists [12]. Since individualist are oriented more toward self interest, reaching their own goal, look out for him/herself and consider their personal achievement, so hotel image and room quality are the most influential factor for their satisfaction [16]. 


\subsubsection{Masculinity/Femininity (MAS)}

The main values of masculine culture are achievement and success while feminine culture cares for others as well as the quality of life. In masculine culture people like to be the winner and they care about success. They teach their children to admire the strong. On the other hand in feminine culture, trying to be the winner is negative and it is not really important to show success. Children learn sympathy for the underdog in this culture. Arabs with their common values are in masculinity culture [7].

\subsubsection{Long-Term Orientation (LTO)}

People with long-term orientation care about future while people with low-term orientation spending for now is more important rather than saving for future. Examples of long term orientation culture are East Asian countries while AngloSaxon societies have low-term orientation culture. Brazil and Netherlands are countries which score medium [7]. According to de Mooij [2] different leisure activities are related to distinct culture dimensions and LTO represent the stability, thrift, tradition and the future respectfulness [17] which in tourist behavior can cause different outcomes.

\section{Hofstede model in tourist behavioral studies}

A number of studies have been acknowledged the importance of Hofstede national culture model in social science, business, marketing etc. Sondergaard [18] asserts that Hofstede's work was cited in 1,000 academic journals between 1980 and 1993 in the area of social science and business disciplines. Having taken the importance of this model, Chandy and Williams [19] mentioned that Hofstede conceptual model is the third most cited model in cross-cultural studies. Moreover, Hofstede is the most well-known name in cultural studies and his cultural model has broadly applied in the literature [6]. The other confirmation about the importance of Hofstede model was given by Reisinger [7] who believes that the most widely developed dimensions of national culture which allows differentiating among cultures can be seen in Hofstede national culture model. To accomplish the significance of Hofstede national culture model, it is highlighted that via just searching through the literature (from 2000 to 2009) by the database Business Source Primer, together with areas like marketing, consumer behavior, consumer preference, brand choice, and tourism109 academic research studies were shown to be published, including the key word "Hofstede"[20].

By reviewing aforementioned thoughts about Hofstede model and lot more, it can be concluded that the best model in cross cultural studies can be Hofstede national culture model. Concerning the tourist behavioral studies, this study use the mentioned model to find the influence of each dimensions of national cultures on tourists behavior towards environment either the environment they choose to visit or the volume of their care for sustainability of environment. 


\section{Importance of environment in tourism}

It is believed that one of the important factors for tourist decision making is the environment of destinations. It is not only important in destination choice but also in the length of stay. Olah [21] in Safaki [22] by referring to the academic estimates of previous studies asserts that the single option for tourist demands determination is environment. He believes that this option remains at least for next 100 years.

Safakli [22] divides tourism destination environment into natural and historical environments. He believes that historical and visual environment should be repaired in a periodical duration as they present the value of the culture of the destination they belong to. Other studies worked on tourists' role in sustainability of environment. How different tourists behave regarding to environment is the focus of their study which some examples will be discussed in next part.

\section{Tourists' national culture and environment}

Numbers of studies have been done about the influence of tourists' national culture on their behavior. The studies cover three stages of tourist behavior including pre-trip, on site and post-trip behavior. Their needs and motivation, information search, decision making which all include in pre trip behavior are affected by internal or external environmental stimuli [7].Reisinger refers to different cultural groups who develop different image and perception products. Different expectation, awareness, benefit demand, choice preference, attitudes, opinions, emotion, travel characteristics, satisfaction and the like are under the influence of different tourists' national culture.

As mentioned above, one of the national culture traits of Hofstede is collectivism. This national culture traits influences consumer search behavior while they are searching for "environmentally friendly" product [23]. Kim and Choi [14] also believes that this trait of national culture control a diversity of social behavior. He refers to the motivation of environmental intentional behavior regarding to individualism or collectivism culture.

Regarding to recycling behavior [24] it is considered that individualists and collectivists have different beliefs. Collectivists have more aspiration to involve in recycling behavior while individualists don't. The reason behind this behavior is since collectivists are more cooperative, they like to help others and group goal is more important for them rather than individual one. On the other hand individualists focus on personal goals which cause less desire for recycling. To support this idea Dunlap and Van Liere [25] refer to resource conservation and $\mathrm{Li}[23]$ to ecological commitments which collectivists are more into them rather than individualists. To sum up Carman [26] and Williams [27] believe that values are the factors to motivate or influence individuals to behave in specific way. Rokeach [3] also emphasize that values cause different actions or judgments. Kim and Choi [14] assert that there is a positive relationship between 
collectivism culture and green purchase behavior and environmental concerns in general.

The Japanese, with high uncertainty avoidance, prefer to visit places with low risks. For example they wish to stay in the environment which is popular among the Japanese. The best example here is hotels and restaurants. They like to eat the same food which they are used to, and therefore trying new things is not their desire. Korean tourists comparing to Japanese are more adventurous in selecting tourism activities and are faster in purchasing [28].Comparing to Japanese and Korean, American with low level of uncertainty avoidance culture prefer to go to the new environments and enjoy the uniqueness.

Surprisingly tourists with high PD participate and spend more on shopping activities comparing to low PD ones. Moreover, low power distance as one dimension of national culture gives details about the desire to visit amusement facilities like theme parks or the zoo [2].

Masculinity and low uncertainty avoidance explain the level of expenditure per vacation trip [2]. It is mentioned that expenditure on packaged holidays are high in masculine culture while in feminine culture tourists spend more on travel than accommodation (less than $25 \%$ of their total holiday budget). In the feminine culture, people have a great connectedness to home than in masculine ones, which influences the way they organize their vacation (the best examples are European who like to travel with their caravan to carry necessary stuff with themselves to feel at home while traveling). This culture causes the lack of interest to stay in hotels. In the opposite way low power distance culture and masculinity one prefers to stay in hotels [2]. Moreover, masculinity/femininity among other dimensions discusses about "material success" vs. "quality of life" [9]. For instance people with masculine culture have high expenditure while in feminine society people prefer to have more leisure time. In this regards, Hofstede argues that people with masculine culture prefer economic growth over environmental conservation [29]. This shows that in masculine culture, people care less about environment.

Lack of study in tourist behavior regarding the influence of long term orientation is clear but as far as people with long term orientation culture care about future comparing to short term orientation ones, keeping environment for future generations would be their desire. The behavioral differences towards environment according to tourist national culture are shown in table 1 . Additional research is needed to add more detailed to the table concerning each national culture dimension.

\section{Conclusion and implication}

Tourism is one of the main industries for many countries, and in addition it is the fastest growing industry in the world. Therefore, the role of environment in this vital industry couldn't be ignored. Tourists make decision to visit a place because of distinct factors and environment of the destination is one of the fundamental aspects in this matter. Moreover, this important element of tourism should be saved for future generation and tourists' behavior toward it requires 
being concerned. To be successful in international tourist industry, policy makers, marketers and managers and all who deal in the industry should learn and understand tourists' cultural differences which influence tourists' behavior.

Table 1: National culture and tourist behavior towards environment.

\begin{tabular}{|c|c|c|}
\hline \multicolumn{2}{|c|}{ National Culture } & \multirow{2}{*}{$\begin{array}{c}\text { Tourist Behavior towards Environment } \\
\text {. Follow the rule and regulation } \\
\text {. Participate more in natural activities }\end{array}$} \\
\hline \multirow{2}{*}{$\begin{array}{l}\text { Power } \\
\text { Distance }\end{array}$} & High & \\
\hline & Low & $\begin{array}{l}\text { Prefer less rule and regulation } \\
\text {. Prefer shopping }\end{array}$ \\
\hline \multirow{2}{*}{ Individualism } & High & $\begin{array}{l}\text {. Care to use environmental friendly product } \\
\text {. Have more ecological commitment }\end{array}$ \\
\hline & Low & $\begin{array}{l}\text { Have no preference in using environmental } \\
\text { friendly product } \\
\text {. Have less ecological commitment }\end{array}$ \\
\hline \multirow{2}{*}{ Masculinity } & High & $\begin{array}{c}\text {. Have high expenditure } \\
\text { There is probability of high level of waste }\end{array}$ \\
\hline & Low & Care less about environmental problem \\
\hline \multirow{2}{*}{$\begin{array}{l}\text { Uncertainty } \\
\text { Avoidance }\end{array}$} & High & $\begin{array}{l}\text {. Prefer to visit new places } \\
\text { Have no problem to go to unfamiliar destination } \\
\text {. Travel in small group or individual }\end{array}$ \\
\hline & Low & $\begin{array}{c}. \text { No desire to visit far destination } \\
\text { Have aspiration to use familiar service and } \\
\text { facilities } \\
\text { Travelling in big group }\end{array}$ \\
\hline \multirow{2}{*}{$\begin{array}{l}\text { Long-Term } \\
\text { Orientation }\end{array}$} & High & $\begin{array}{l}\text {. Concern about future } \\
\text { Care about next generation use of environment } \\
\text {. Don't want to lose face }\end{array}$ \\
\hline & Low & Present happiness \\
\hline
\end{tabular}

\section{References}

[1] Schiffman Leon G., \& Kanuk Leslei L., Consumer Behavior. Seventh Edition Published by Prentice Hall Sixth edition, 2000.

[2] De Mooij M., Consumer Behavior and Culture. Consequences for global marketing and advertising, 2004. 
[3] Rokeach, M., The Nature of Human Values, New York: Free Press, 1973.

[4] Hofstede, G., Motivation, leadership, and organization: do American theories apply abroad? Organizational dynamics, 9, 42-63: Hofstede, G. 1983. National culture in four dimensions: a research based theory of cultural differences among nations. International study of management and organization, 13, 46-75, 1980.

[5] Jnadt, F., E., An Introduction to Intercultural Communication: Identities in Global Community. SEGE Publication Inc., 2006.

[6] Litvin Stephen W., Crotts John C., \& Hefner Frank L., Cross-cultural Tourist bahavior: a Replication and Extension involving Hofstede's Uncertainity Avoidance Dimension. The International Journal of Tourism Research, pp. 29-37, 2004.

[7] Reisinger Y., International Tourism Culture and Behavior. Elsevier Ltd., 2009.

[8] Lynn, Michael, George M. Zinkhan \& Judy Harris, Consumer Tipping: A Cross-Country Study. Journal of Consumer Research, 20 (December), pp. 478-485 1993.

[9] Hofstede, G., Culture's recent consequences: Using dimension scores in theory and research. International Journal of cross cultural management, 1 (1), pp. 11-30, 2001.

[10] Money, R. B. \& Crotts, J. C., The effect of uncertainty avoidance on information search, planning, and purchases of international travel vacations. Tourism Management 24(2): pp. 191-202, 2003.

[11] Gregory, G. D. \& Munch, J. M., Reconceptualizing individualism /collectivism in consumer behavior. Advances in Consumer Research. 23(1), pp. 104-110, 1996.

[12] Tuzun, I. K. \& Devrani, T., K., The Link between Hotel Attributes and Customer Satisfaction: The role of individualism/collectivism orientation. European Applied Business Research Conference, 7-10 June, Dublin, Ireland, 2010.

[13] Richins M. L. \& Verhange, B. J., Cross-cultural Differences in Consumer Attitudes and Their Implication for Complaint management. International Journal of Research in Marketing, 2 (3), pp. 197-206, 1985.

[14] Kim, Y. \& Choi. S. M., Antecedent of Green Purchase Behaviour: An Examination of Collectivism, Environmental Concern, and PCE, in Advances in Consumer Research Vol. 32, eds. Geeta Menon and Akshay R. Rao, Duluth, MN: Association for Consumer Research, pp. 592-599, 2005.

[15] Reichert, C.F. \& Gill, T.G., Effect of Cultural Distance on Customer Service Satisfaction: A theoretical framework and research agenda. Advances in Consumer Research, 31, pp. 202-207, 2004.

[16] Triandis, H.C, Cross-cultural studies of individualism and collectivism, In Nebraska Symposium on Motivation, John J. Berman, (ed), 37, pp. 41-133, 1990.

[17] Meng, F., Individualism/collectivism and group travel behavior: acrosscultural perspective. International Journal of Culture, Tourism and Hospitality, 4 (4). pp. 340-351 2010. 
[18] Sondergaard, M., Hofstede's consequences: A study of reviews, citations and replications. Organisation Studies, 15 (3), pp. 447-456, 1994.

[19] Chandy P. R. \& Williams T. G., The impact of journals and authors on international business research: a critical analysis of JIBS articles. Journal of International Business studies. 25 (4), pp. 715-725, 1994.

[20] Reisinger Y. \& Crotts, J., C., Applying Hofstede's National Culture Measures in tourism Research: Illuminating Issues of Divergence and Convergence. Journal of Travel Research 2010 49,pp. 153, 2009.

[21] Olah, H., External Publicity and Tourism. Cultural Business Publicatin Bank. 253, Ankara, 2000.

[22] Safakli, O., The Importance of Environment for the Tourism Sector of T RNC within the Context of Environmental Issue of the Mediterranean Region. Journal of Economics, Business Administration, International Relations and Political Science. 1(2), pp. 11-19, 2001.

[23] Li, Ling-Yee, Effects of Collectivist Orientation and Ecological Attitude on Actual Environmental Commitment: The Moderating Role of Consumer Demographics and Product Involvement. Journal of International Consumer Marketing, 9, pp. 31-53, 1997.

[24] McCarty, John A. \& Shrum, L. J., A Structural Equation Analysis of the Relationships of Personal Values, Attitudes and Beliefs about Recycling, and the Recycling of Solid Waste Products, in Advances in Consumer Research, Vol. 20, L. McAlister and M. Rothschild, eds., Provo, UT: Association for Consumer Research, pp. 641-646 1993.

[25] Dunlap, Riley E. \& Kent D. Van Liere, The New Environmental Paradigm. Journal of Environmental Education, 9 (4), 10-19, 1978.

[26] Carman, James M., Values and Consumption Patterns: A Closed Loop, in Advances in Consumer Research, Vol. 5, H. Keith Hunt, ed., Ann Arbor, MI: Association for Consumer Research, pp. 403-407, 1978.

[27] Williams, R. M., Jr., Change and Stability in Values and Value Perspectives: A Sociological Perspectives, in Understanding Human Values: Individual and Societal, M. Rokeach, ed., New York: Free Press, 1979.

[28] March, R., Diversity in Asian outbound travel industries: A comparison between Indonesia, Thailand, Taiwan, South Korea, and Japan. International Journal of Hospitality Management, 16(2), 231-239, 1997.

[29] Hofstede, G., Culture and Organization: Software of the Mind, New York: McGraw Hill 1997. 